\title{
PENINGKATAN MINAT MEMBACA WARGA BELAJAR MELALUI KAMPUNG LITERASI DI PKBM AL-HIDAYAH TASIKMALAYA
}

\author{
Wiwin Herwina \\ Pendidikan Masyarakat, FKIP, Universitas Siliwangi \\ wiwinherwina@unsil.ac.id
}

\begin{abstract}
Abstrak
Membaca sangat penting bagi kehidupan manusia. Namun demikian, minat membaca warga belajar di Indonesia sampai dengan sekarang ini sangatlah rendah. Rendahnya minat baca di Indonesia dilihat dari beberapa bukti-bukti maupun riset yang sudah dilakukan. Hal tersebut mendorong penulis untuk mengkaji kampung literasi dalam meningkatkan minat baca warga di PKBM AL-Hidayah Tasikmalaya.Tujuan penelitian ini adalah untuk mengkaji mengenai peningkatan minat membaca warga belajar melalui Taman Bacaan Masyarakat di PKBM Al-Hidayah Tasikmalaya. Kajian ini menggunakan metode penelitian dan mengembangkan teknik studi kasus,data dianalisis secara deskriptif kualitatif.starategi yang dilakukan dalam meningkatkan minat baca warga belajar melalui pembiasaan terhadap kegiatan membaca berbagai wacana dan teks buku yang disediakan serta adanya pendampingan dari pihak pengelola PKBM dalam meningkatkan minat baca memberikan informasi sebagai motivator agar tumbuhnya,kepercayaan diri dan ada kemauan untuk membaca, serta sebagai sumber hiburan masyarakat Hasil temuan menunjukan dengan adanya kampung literasi warga belajar lebih peduli dan kondusip terhadap lingkungan sekitar, adanya kecintaan gemar terhadap pembiasaan membaca, warga belajar lebih kreatif dalam mengumpulkan data informasi yang di butuhkan melalui teks buku bacaan.
\end{abstract}

Kata kunci: Peningkatan, minat, membaca, literasi.

\begin{abstract}
Reading is very important for human life. However, up to now, the reading interest of learning citizens in Indonesia has been very low. The low interest in reading in Indonesia can be seen from the evidence and research that has been done. This prompted the author to study literacy villages in increasing the reading interest of residents in PKBM AL-Hidayah Tasikmalaya. The purpose of this study was to examine the increase in reading interest in learning citizens through Community Reading Gardens at PKBM Al-Hidayah Tasikmalaya. This study uses research methods and develops case study techniques, the data is analyzed descriptively qualitatively. The strategies carried out in increasing the reading interest of learning citizens through familiarizing themselves with reading various discourses and textbooks are provided as well as assistance from PKBM managers in increasing reading interest. information as a motivator for growth, self-confidence and a willingness to read, as well as a source of community entertainment The findings show that with a literacy village, residents learn to care more about and are conducive to the surrounding environment, there is a fondness for reading habits, learning citizens are more creative in collecting data information needed through text books.
\end{abstract}

Keywords: Improvement, interest, reading, literacy

\section{PENDAHULUAN}

Membaca adalah kegiatan mentransfer data dari bahan bacaan menjadi informasi dan diolah menjadi pengetahuan yang dapat mengubah sikap/tindakan seseorang yang kemudian diimplementasikan menjadi kebijakan. Ciri suatu masyarakat yang sudah maju jamak disebut masyarakat informasi salah satunya adalah kebutuhan informasi yang tinggi yang notabene didapatkan dengan cara membaca. Kebiasaan membaca yang berbobot dan dilakukan secara terus menerus dikatakan sebagai minat membaca. Kebutuhan akan pengetahuan pada dasarnya merupakan kebutuhan untuk melakukan perubahan dari dalam jiwa, akal dan budi pakerti. 
Informasi yang dipelajari tanpa disadari dapat menjadi dasar perkembangan sikap dan karakter manusia. Membaca perlu dijadikan kebiasaan yang harus ditanamkan sejak dini, manusia yang suka membaca punya potensi untuk maju dan berkembang pengetahuannya untuk menopang eksistensinya. Membaca sangat penting bagi kehidupan manusia. Kegiatan membaca buku merupakan kegiatan kognitif yang mencakup proses penyerapan pengetahuan, pemahaman, kemampuan analitis, kemampuan sintetis, dan kemampuan evaluasi (Shofaussamawati, 2014:50) Membaca mempunyai peranan sosial yang penting dalam kehidupan manusia. Selain itu, membaca merupakan modal utama untuk kemajuan suatu bangsa. Sebab, sebagian besar proses pendidikan bergantung pada kemampuan dan kesadaran akan membaca.

Membaca dapat dijadikan tolak ukur keberhasilan pendidikan suatu negara. Negara dengan tingkat minat membaca yang tinggi akan menghasilkan penduduk yang kaya akan ilmu pengetahuan. Namun demikian, minat membaca warga belajar di Indonesia sampai dengan sekarang masih rendah. Hal tersebut dapat dilihat dari beberapa bukti-bukti maupun riset yang sudah dilakukan. Menurut Badan Pusat statistik (BPS) tahun 2006 dalam (Siswati,24:2010) bahwa minat membaca warga belajar Indonesia sangat rendah karena masyarakat belum menempatkan membaca sebagai sumber utama mendapatkan informasi masayarakat lebih memilih menontor televisi $(85,9 \%)$ dan mendengarkan radio hanya $40,3 \%$ sedangkan untuk aktivitas membaca lebih sedikit $(23,5 \%)$ yang artinya masyarakat Indonesia dalam menerima informasi yang di terima ternyata minat baca kurang di banding dengan menonton televisi dan mendengarkan radio maka dalam meningkatkan minat baca dalam menambah wawasan dan pengetahuan perlu adanya upaya dari berbagai lembaga yang ada di masyarakat dan pemerintah salah satunya program literasi.

Hasil survei beberapa lembaga menunjukkan tingkat minat baca masyarakat Indonesia masih rendah. Bahkan di bawah rata-rata tingkat minat baca negara Asia lainnya. Berdasarkan data UNESCO tahun 2012, indeks minat baca masyarakat Indonesia baru mencapai 0,001. Artinya, dari 1.000 penduduk hanya satu warga yang tertarik untuk membaca. Data UNESCO untuk indeks pembangunan pendidikan, Indonesia berada di nomor 69 dari 127 negara. Secara nasional, tidak sampai satu judul buku yang dibaca seseorang dalam setahun. Hasil survei UNESCO, daerah di Indonesia yang minat bacanya paling tinggi adalah Daerah Istimewa Yogyakarta dengan indeks baca 0,049. Di Singapura, indeks baca masyarakatnya sudah mencapai 0,45 . Data yang menggembirakan adalah capaian pemberantasan buta aksara di Indonesia. Hasil sensus Badan Pusat Statistik (BPS) di tahun 2015 yang merupakan tahun pertama Rencana Pembangunan Jangka Menengah Nasional (RPJMN) 2015-2019, jumlah buta aksara di Indonesia tinggal 5.984.075 orang atau 3,70\%. Dengan berbagai program pemberantasan buta aksara yang dilakukan Kementerian Pendidikan dan Kebudayaan (Kemendikbud), angka buta aksara ini mengalami penurunan yang sangat signifi kan dibandingkan tahun-tahun sebelumnya.

Data minat baca dan tingkat buta aksara tersebut berpengaruh terhadap posisi Human Development Index (HDI) Indonesia. HDI berkaitan dengan Indeks Pembangunan Manusia (IPM) yang diukur dari usia harapan hidup (tingkat kesehatan), pertumbuhan ekonomi dan kualitas pendidikan. Data BPS, tahun 2014 nilai HDI mengalami kenaikan tipis menjadi 68,90 dari 68,4 di tahun 2013. Data yang dirilis United Nations Development Program (UNDP), HDI 
Indonesia di tahun 2013 berada di peringkat ke-108 dari 187 negara. Angka HDI ini menunjukkan bahwa Indonesia juga berada jauh di bawah sejumlah negara di ASEAN. Hasilhasil survei tersebut menunjukkan gentingnya persoalan minat baca dan literasi di Indonesia. Sebagai negara dengan jumlah penduduk mencapai 270.234.842 jiwa, peringkat keempat dari segi jumlah penduduk terbanyak di dunia, dari segi minat baca dan HDI Indonesia jauh tertinggal dibandingkan negara lain. Berbekal pengalaman dalam pemberantasan buta aksara, bukan hal yang mustahil jika kita secara bersama-sama dan berupaya melakukan berbagai hal bahkan yang out of the box, kita bisa meningkatkan minat baca dan literasi masyarakat.

Pemerataan layanan pendidikan pada masyarakat terus dilakukan oleh pemerintah dengan bekerja sama dengan instansi terkait melalui berbagai program dan kebijakan yang dikeluarkan. Salah satu program yang diselenggarakan oleh Pemerintah melalui Direktorat Pembinaan Pendidikan Keaksaraan dan Kesetaraan adalah Kampung Literasi. Hal ini sebagai bentuk pengembangan layanan pendidikan yang lebih komprehensif sehingga masyarakat memiliki pengetahuan yang luas dan mendalam terhadap sejumlah informasi yang berkaitan dengan kehidupannya.

\section{KAJIAN TEORI}

Kampung Literasi merupakan sebuah kawasan kampung yang menyediakan berbagai layanan pendidikan pendukung multiaksara. Dengan demikian, masyarakat diharapkan dapat melibatkan diri secara aktif dalam pengembangan kompetensi keaksaraan baik dasar, lanjutan, maupun multi aksara agar memiliki wawasan dan kompetensi yang memadai dalam menjalankan aktivitasnya. Kampung Literasi digunakan untuk mewujudkan masyarakat melek aksara (dasar, lanjutan, maupun multi aksara) agar memiliki pengetahuan dan pemahaman yang lebih luas. Kampung Literasi merupakan salah satu program Direktorat Pendidikan Keaksaraan dan Kesetaraan dalam rangka mewujudkan masyarakat yang berpengetahuan, berketerampilan, maju, dan mandiri melalui kegiatan membaca dan berlatih agar memiliki pemahaman yang luas. Keberadaan Kampung Literasi akan memberikan perluasan akses informasi kepada masyarakat, menumbuhkan dan membudayakan minat baca, mengembangkan sikap positif, dan mengembangkan keterampilan.

PKBM sebagai satuan pendidikan nonformal merupakan layanan pendidikan yang diselenggarakan untuk memberdayakan masyarakat melalui pendidikan kecakapan hidup, pendidikan anak usia dini, pendidikan kepemudaan, pendidikan pemberdayaan perempuan, pendidikan keaksaraan, pendidikan keterampilan dan pelatihan kerja, pendidikan kesetaraan, serta pendidikan lain yang ditujukan untuk mengembangkan kemampuan peserta didik. "Kegiatan pengabdian akan diberikan dalam bentuk pelatihan teknik mengembangkan kemampuan literasi dimana ketrampilan ini dapat dimanfaatkan oleh pengelola untuk memberikan pelatihan kepada anak-anak pengguna TBM agar memiliki kompetensi literasi yang baik. Dan pelatihan menulis akan memberikan ketrampilan tulis menulis dan menghasikan tulisan yang layak jual sehingga kegiatan menulis dapat menjadi salah satu sumber pendapatan ". (Sewagati, 2018)

PKBM sebagai salah satu program pendidikan luar sekolah serta dalam rangka ikut mencerdaskan bangsa serta usaha melestarikan program Pendidikan luar sekolah melalui 
sebuah program pemberdayaan masyarakat untuk pengembangan gerakan literasi serta pengembangan minat membaca pada masyarakat akan peningkatan pengetahuan dan wawasan yang lebih baik dan berarah pada progres atas kehidupan serta berkepribadian baik pribadi, kelompok maupun dalam bermasyarakat.

Berdasarkan latar belakang penelitian di atas, maka rumusan masalah yang diajukan dalam penelitian ini adalah: bagaimana meningkatkan minat baca warga belajar pada kampung literasi di PKBM AL-Hidayah Tasikmalaya. Adapun tujuan dari penelitian peningkatan minat membaca warga belajar melalui Taman Bacaan Masyarakat di PKBM Al-Hidayah Tasikmalaya

Penelitian ini diharapkan dapat memberikan pertimbangan dan sumbangan dalam pengembangan konsep-konsep teoretis yang berkaitan dengan pembinaan minat membaca dan memberikan gambaran mengenai pembinaan minat membaca sehingga dapat menjadikan alternatif pemecahan masalah dan memunculkan kreativitas serta inovasi dalam pelaksanaannya.

Tinjauan pustaka dalam penelitian ini berkaitan dengan konsep minat membaca dan kampung literasi. Minat membaca merupakan kebiasaan yang diperoleh setelah seseorang dilahirkan. Dengan demikian minat baca bukanlah kebiasaan bawaan. Oleh karena itu minat membaca dapat dipupuk, dibina, dan dikembangkan. Dalam era pembangunan dewasa ini peranan minat baca sangat penting karena dengan minat membaca seseorang dapat memperoleh pengertian yang lebih mendalam tentang suatu gejala, dapat menganalisis aspekaspek yang dibaca, serta dapat mengaitkan dengan berbagai gejala lain. Secara singkat dengan membaca akan diperoleh hasil, baik informasi, pengertian, pengetahuan, keterampilan, motivasi, maupun fakta seperti yang disajikan oleh bahan bacaan.

Kampung literasi merupakan kawasan kampung yang digunakan untuk mewujudkan masyarakat melek aksara (dasar, lanjutan, maupun multi aksara) agar memiliki pengetahuan dan pemahaman yang lebih luas. Kampung Literasi merupakan salah satu program Direktorat Pendidikan Keaksaraan dan Kesetaraan dalam rangka mewujudkan masyarakat yang berpengetahuan, berketerampilan, maju, dan mandiri melalui kegiatan membaca dan berlatih agar memiliki pemahaman yang luas. Keberadaan Kampung Literasi akan memberikan perluasan akses informasi kepada masyarakat, menumbuhkan dan membudayakan minat baca, mengembangkan sikap positif, dan mengembangkan keterampilan. Hal ini juga sebagai wujud dalam menciptakan masyarakat pembelajar sepanjang hayat (lifelong learning).

Penyelenggaraan program Kampung Literasi dimaksudkan untuk memberikan layanan pengetahuan, informasi dan keterampilan kepada masyarakat sehingga memiliki kecakapan dan wawasan yang luas serta keterampilan yang memadai. Model pemberdayaan Kampung Literasi bertujuan untuk mendukung program pemerintah dalam mengatasi permasalahan, pembinaan dan menghidupkan aktivitas literasi secara berkelanjutan di masyarakat. Tujuan khusus dari penyelenggaraan program Kampung Literasi ini antara lain: 1) Menyediakan layanan informasi dan pengetahuan di jalur pendidikan nonformal kepada masyarakat. Layanan tersebut berupa buku dan non-buku yang disediakan di TBM, pojok baca atau sejenisnya, serta dilengkapi dengan teknologi informasi; 2) Meningkatkan pengetahuan, keterampilan, dan sikap masyarakat sehingga memiliki kualitas hidup yang baik Mengembangkan minimal dua dari enam komponen literasi, yaitu literasi baca-tulis, literasi berhitung, literasi sains, literasi 
teknologi informasi dan komunikasi (TIK), literasi keuangan, literasi budaya dan kewarganegaraan; (Kementerian Pendidikan dan Kebudayaan, 2017: 4).jadi yang diterapkan dalam pelaksanaan program kampong literasi yang dikaji yaitu yaitu literasi baca-tulis, literasi berhitung,

Hasil yang ingin dicapai dalam penyelenggaraan program Kampung Literasi adalah: 1) Tersedianya layanan pengetahuan dan informasi pada jalur pendidikan nonformal berupa buku maupun non-buku yang tersedia di TBM, pojok baca, atau sejenisnya, yang dilengkapi dengan teknologi informasi; 2) Masyarakat memiliki pengetahuan, keterampilan dan pengembangan sikap yang positif sehingga memiliki kualitas hidup yang baik;

\section{METODE PENELITIAN}

Penelitian ini merupakan jenis penelitian kualitatif, dengan metode penelitian yaitu metode studi kasus. Menurut Imam Gunawan (2013: 115), metode studi kasus sebagai salah satu jenis pendekatan deskriptif, penelitian yang dilakukan secara intensif, terperinci, dan mendalam terhadap suatu organisme (individu), lembaga atau gejala tertentu dengan daerah atau subjek yang sempit.

Penelitian dilakukan pada PKBM Al-Hidayah Kabupaten Tasikmalaya Propinsi Jawa Barat yang beralamat di Jln. Raya Selatan Cijaha RT/RW 03/02 Desa Simpang, Kecamatan Bantarkalong Kabupaten Tasikmalaya. Waktu pelaksanaan penelitian berlangsung selama 6 (enam) bulan, yaitu dari bulan April 2020 sampai dengan September 2020.Sumber data diidentifikasikan menjadi 3 yaitu person, place, dan paper.Person yaitu sumber data berupa orang yang bisa memberikan data berupa jawaban lisan melalui wawancara. Dalam penelitian ini personnyayaitupengurus PKBM, ketua PKBM, pengelola PKBM, tutor, dan masyarakat sekitar yang berjumlah 10 orang.Place yaitu sumber data berupa tempat atau sumber data yang menyajikan tampilan berupa keadaan diam dan bergerak, meliputi fasilitas gedung, kondisi lokasi, kegiatan belajar-mengajar, kinerja, aktifitas dan sebagainya yang ada di PKBM AlHidayah Tasikmalaya. Paper yaitu data berupa simbol atau sumber data berupa benda-benda tertulis seperti buku-buku arsip, catatan-catatan, dokumen yang ada diPKBM Al-Hidayah Tasikmalaya. Metode pengumpulan data yang dilakukan pada penelitian ini meliputi observasi dan wawancara. Data yang terkumpul dalam proses penelitian selanjutnya dianalisis kualitatif, yaitu analisis dan interpretasi dilakukan secara kritis. Adapun langkah-langkah yang diterapkan peneliti dalam menganalisa data yaitu mengikuti alur yang dinyatakan oleh Salim \& Formen (2006:22) yaitu: pengumpulan data, penyajian data, reduksi data, kesimpulan dan verifikasi.

\section{HASIL DAN PEMBAHASAN}

\section{Hasil}

Proses pendampingan dan motivasi yang diberikan oleh PKBM melalui Taman Bacaan Masyarakat selain diberikanya sosialisasi agar masyarakat memiliki kepercaaayaan diri dan berapresiasi dalam kegiatan membaca dengan menyiapkan segala buku teks bacaan agar warga belajar dan masyarakat memiliki kesadaran untuk membaca dalam waktu luang dan menyempatkan waktu untuk membaca secara rutinitas untuk belajar di taman bacaan diharapkan dengan adanya kampung literasi dapat memaksimalkan kegiatan budaya baca 
dengan tujuan agar warga belajar lebih kreatif resposif ,kondusif di dalam lingkungan dalam memanfaatkan fasilitas yang disiapkan di PKBM AL-Hidayah.

Berdasarkan hasil wawancara dengan pengelola PKBM Al-Hidayah Kabupaten Tasikmalaya diperoleh informasi bahwa kampung literasi merupakan kawasan kampung yang digunakan untuk mewujudkan masyarakat melek aksara (dasar, lanjutan, maupun multi aksara) agar memiliki pengetahuan dan pemahaman yang lebih luas. Dengan demikian, masyarakat diharapkan dapat melibatkan diri secara aktif dalam pengembangan kompetensi keaksaraan baik dasar, lanjutan, maupun multi aksara agar memiliki wawasan dan kompetensi yang memadai dalam menjalankan aktivitasnya. Kampung Literasi digunakan untuk mewujudkan masyarakat melek aksara (dasar, lanjutan, maupun multi aksara) agar memiliki pengetahuan dan pemahaman yang lebih luas. Kampung Literasi merupakan salah satu program Direktorat Pendidikan Keaksaraan dan Kesetaraan dalam rangka mewujudkan masyarakat yang berpengetahuan, berketerampilan, maju, dan mandiri melalui kegiatan membaca dan berlatih agar memiliki pemahaman yang luas. Keberadaan Kampung Literasi akan memberikan perluasan akses informasi kepada masyarakat, menumbuhkan dan membudayakan minat baca, mengembangkan sikap positif, dan mengembangkan keterampilan.

PKBM Al-Hidayah Kabupaten Tasikmalaya menyelenggarakan Kampung Literasi sebagai salah satu program Direktorat Pendidikan Keaksaraan dan Kesetaraan dalam rangka mewujudkan masyarakat yang berpengetahuan, berketerampilan, maju, dan mandiri melalui kegiatan membaca dan berlatih agar memiliki pemahaman yang luas. Keberadaan Kampung Literasi akan memberikan perluasan akses informasi kepada masyarakat, menumbuhkan dan membudayakan minat baca, mengembangkan sikap positif, dan mengembangkan keterampilan. Hal ini juga sebagai wujud dalam menciptakan masyarakat pembelajar sepanjang hayat (lifelong learning).

Menurut salah seorang tutor PKBM Al-Hidayah Kabupaten Tasikmalaya diketahui bahwa penyelenggaraan program Kampung Literasi dimaksudkan untuk memberikan layanan pengetahuan, informasi dan keterampilan kepada masyarakat sehingga memiliki kecakapan dan wawasan yang luas serta keterampilan yang memadai.

Menurut salah seorang tutor PKBM Al-Hidayah Kabupaten Tasikmalaya bahwa Kampung Literasi bertujuan untuk mendukung program pemerintah dalam mengatasi permasalahan, pembinaan dan menghidupkan aktivitas literasi secara berkelanjutan di masyarakat.

Adapun tujuan khusus dari penyelenggaraan program Kampung Literasi ini antara lain:

1) Menyediakan layanan informasi dan pengetahuan di jalur pendidikan nonformal kepada masyarakat. Layanan tersebut berupa buku dan non-buku yang disediakan di TBM, pojok baca atau sejenisnya, serta dilengkapi dengan teknologi informasi;

2) Mengembangkan minimal dua dari enam komponen literasi, yaitu literasi baca-tulis, literasi berhitung, literasi sains, literasi teknologi informasi dan komunikasi (TIK), literasi keuangan, literasi budaya dan kewarganegaraan;

3) Meningkatkan pengetahuan, keterampilan, dan sikap masyarakat sehingga memiliki kualitas hidup yang baik 
Menurut pengelola pengurus PKBM Al-Hidayah Kabupaten Tasikmalaya, proses penyelenggaraan program Kampung Literasi dapat dilakukan dengan tahapan-tahapan berikut ini;

\section{Persiapan}

Pengelola yang sudah mendapat persetujuan untuk menyelenggarakan program Kampung Literasi, melakukan persiapan dan berkoordinasi dengan warga masyarakat dan pemerintah daerah setempat. Selain untuk izin pelaksanaan kegiatan, dengan adanya koordinasi ini, kegiatan Kampung Literasi bisa mendapatkan dukungan dan menjadi agenda pemerintah daerah dan masyarakat.

\section{Penyusunan Jadwal}

Kegiatan Selama 12 Bulan Tim pelaksana Kampung Literasi menyusun draft rangkaian kegiatan di Kampung Literasi selama 12 bulan yang dikemas dalam bentuk kalender kegiatan. Draft kegiatan ini kemudian disampaikan ketika sosialisasi Kampung Literasi.

\section{Sosialisasi dan Publikasi Kepada Masyarakat}

Sosialisasi Kampung Literasi kepada masyarakat menjadi tahapan yang penting agar masyarakat bisa mendukung dan terlibat secara aktif. Sosialisasi dapat dilakukan dengan cara tatap muka atau musyawarah kampung.

Kegiatan sosialisasi dilakukan melalui kampanye dan penjaringan anggota Kampung Literasi yang akan mendapatkan layanan rutin ke rumah dan dusun dimana anggota menetap. Memberikan sosialiasi, penyadartahuan, dan pembinaan masyarakat agar mau menggunakan dan memanfaatkan taman bacaan dan pusat belajar untuk meningkatkan pengetahuan dan wawasan.

Pada saat sosialisasi, pelaksana Kampung Literasi dapat menginformasikan draft rangkaian kegiatan selama 12 bulan yang telah disusun. Masyarakat dapat diajak untuk memberikan masukan dan kemudian sama-sama menyusun rangkaian kegiatan yang disesuaikan dengan kebutuhan masyarakat. Dengan skema ini, secara tidak langsung, pengelola Kampung Literasi sudah melibatkan dan membuat masyarakat menjadi bagian dari Kampung Literasi. Dalam sesi sosialisasi ini, pengelola juga bisa melakukan pembentukan tim pelaksana program yang berasal dari berbagai unsur. Dengan keterlibatan berbagai unsur masyarakat dalam tim pelaksana, diharapkan seluruh rangkaian kegiatan bisa terlaksana dengan baik dan tujuan penyelenggaraan Kampung Literasi dapat tercapai. Publikasi kegiatan juga diperlukan agar masyarakat luas dapat mengetahui rangkaian kegiatan yang akan dilakukan maupun yang sudah dilakukan. Publikasi ini juga bisa memberikan inspirasi bagi masyarakat dan pengelola atau penggiat literasi lainnya. Publikasi dapat dilakukan melalui brosur, majalah dinding (mading), Koran Kampung, leafl et digital dan media sosial.

\section{Pengadaan Bahan Bacaan, Perlengkapan dan Peralatan TBM dan Pojok Baca}

Taman Bacaan ini adalah pusat bahan bacaan dan informasi yang terpusat di PKBM Al Hidayah dan melakukan layanan literasi dan penyediaan bahan bacaan bagi masyarakat di Desa Simpang. Kegiatan belajar dan pelatihan akan dilaksanakan di PKBM Al-Hidayah atau disesuaikan kesepakatan masyarakat.

Bahan bacaan, perlengkapan dan peralatan TBM atau Pojok Baca menjadi komponen yang sangat penting. Pengadaan bacaan, perlengkapan dan peralatan TBM atau Pojok Baca 
yang menggunakan dana dari Kemendikbud, harus sesuai dengan spesifi kasi dan jumlah yang telah diajukan ke Kemendikbud. Pengelola Kampung Literasi, bisa juga mendapat dukungan untuk pengadaan bacaan, perlengkapan dan peralatan TBM atau Pojok Baca dari sumber lainnya, seperti alokasi dana desa, dana pemerintah daerah, menghimpun donasi dari masyarakat, tanggung jawab social (CSR) perusahaan dan lainnya.

\section{Kegiatan Literasi}

Tim pelaksana Kampung Literasi dapat berkreasi secara bebas dalam menyusun dan melaksanakan berbagai program literasi dengan mengacu pada 6 komponen literasi. Kampung Literasi minimal mengembangkan 2 komponen literasi yang sesuai dengan kebutuhan masyarakat sekitar. Rangkaian kegiatan Kampung Literasi dapat dilakukan dengan skema tatap muka dan melalui dunia maya. Kegiatan tatap muka dalam bentuk seperti bedah buku, pelatihan menulis, lomba menulis, pentas seni, kegiatan di pojok-pojok baca, dsb. Sedangkan kegiatan melalui dunia maya dapat melakukan diskusi, tukar pikiran dan urun rembug melalui email dan aplikasi sosial media WhatsApp.

Selain tim pelaksana, pengelola Kampung Literasi juga dapat mengajak masyarakat untuk menjadi relawan yang mengelola TBM atau pojok baca. Sehingga layanan baca dan layanan informasi mengenai Kampung Literasi kepada masyarakat dapat dilakukan sepanjang waktu.

\section{Memberikan pelatihan-pelatihan dan pembinaan masyarakat bidang literasi dan pendidikan.}

Memberikan pelatihan-pelatihan tentang literasi dan pendidikan berupa pelatihan jurnalistik yang bertempat PKBM Al-Hidayah Kabupaten Tasikmalaya. Untuk meningkatkan kemampuan literasi dan minat membaca bagi pelajar, maka PKBM Al-Hidayah Kabupaten Tasikmalaya melakukan pelatihan jurnalistik dengan berbagai kegiatan yaitu Memberikan materi tentang literasi:

1) Mengenalkan ragam metode membaca yang baik

2) Menonton film literasi dan diskusi

3) Memotivasi untuk gemar membaca dan belajar

4) Memberikan layanan membaca buku

5) Mengajarkan peserta untuk membuat artikel atau tulisan ilmiah.

Menurut pengurus PKBM Al-Hidayah Kabupaten Tasikmalaya diketahui bahwa hasil yang ingin dicapai dalam penyelenggaraan program Kampung Literasi adalah:

1) Tersedianya layanan pengetahuan dan informasi pada jalur pendidikan nonformal berupa buku maupun non-buku yang tersedia di TBM, pojok baca, atau sejenisnya, yang dilengkapi dengan teknologi informasi;

2) Masyarakat memiliki pengetahuan, keterampilan dan pengembangan sikap yang positif sehingga memiliki kualitas hidup yang baik;

3) Tersedianya layanan informasi dan sumber akses informasi kepada masyarakat yang berkaitan dengan 6 komponen literasi, yaitu literasi baca tulis, literasi berhitung, literasi sains, literasi teknologi informasi dan komunikasi (TIK), literasi keuangan serta literasi budaya dan kewarganegaraan. 
Tidak sekedar pencapaian dari setiap kegiatan program Kampung Literasi yang dapat terlaksana dan berhasil. Tetapi lebih dari itu, program ini telah menghantarkan PKBM AlHidayah Kabupaten Tasikmalaya mendapat penghargaan dari pemerintah sebagai PKBM yang telah mengembangkan program Literasi di tingkat Desa. Apresiasi ini bukti bahwa PKBM AlHidayah Kabupaten Tasikmalaya telah memberikan dampak yang sangat baik terhadap pembangunan sumberdaya manusia pedesaan, dan pemerintahan Kabupaten Tasikmalaya sangat menyambut baik inisasi program pengembangan Kampung Literasi.

\section{Pembahasan}

Mengembangkan minat baca masyarakat melalui Pemberdayaan dengan menekankan pada penciptaan lingkungan membaca untuk semua jenis bacaan, pada semua lapisan masyarakat tanpa membedakan usia, pendidikan, kedudukan, dan social budaya seseorang. Berdasarkan apa yang dikatakan oleh Sudarsana (2015: 1.14) tujuan khusus dari pembinaan minat baca adalah sebagai berikut: 1) Mewujudkan suatu sistem untuk penumbuhkembangan minat baca sesuai dengan kebutuhan masyarakat; 2) penumbuh kembangan minat baca yang sesuai dengan kebutuhan masyarakat dan pembangunan; 3) Menumbuhkembangkan minat baca semua lapisan masyarakat untuk mengantisipasi perkembangan ilmu pengetahuan dan teknologi; 4) Menyediakan berbagai jenis koleksi perpustakaan sebagai bahan bacaan sesuai dengan kebutuhan pengguna jasa perpustakaan; 5) Mengembangkan minat dan selera dalam membaca. 6) Terampil dalam menyeleksi dan menggunakan buku; 7) Mampu mengevaluasi materi bacaan dan memiliki kebiasaan efektif dalam membaca informasi; dan 8) Memiliki kesenangan dalam membaca. Layanan pendidikan non formal yakni Kampung Literasi supaya dapat memenuhi kebutuhan informasi yang diperlukan oleh masyarakat yang berada dalam kampung tersebut. Sehingga dapat dikatakan bahwa pemberdayaan masyarakat dapat dilakukan dengan konsep yang ada pada Kampung Literasi dengan mengusung konsep community based library. Perpustakaan dan layanan informasi berbasis masyarakat membantu Individu dan kelompok dengan pemecahan masalah sehari-hari dan dengan partisipasi dalam proses demokrasi.

\section{PENUTUP}

Dengan mengikuti kegiatan yang dilaksanakan oleh PKBM melalui gerakan taman Bacaan di harapkan warga belajar menjadi gemar membaca menjadi generasi yang tangguh dan handal bertanggung jawab dapat menampung pengetahuan dan dapat menerima berbagai informasi yang lebih positip didukung dengan adanya tanggung jawab serta dapat memecahkan permasalahan yang dihadapi dan masyarakat menjadi kreatif dan kondusif dalam menjaga didalam pelaksanaan kegiatan PKKBM AL-Hidayah hendaknya dilaksanakan kegiatan lain sebagai hiburan bagi masyarakat seperti mempraktekan isi buku (keterampilan), mendiskusikan isi buku baru, lomba-menulis, memasak dan mengadakan acara cerdas cermat.

\section{DAFTAR PUSTAKA}

Gunawan, Imam.(2013). Metode Penelitian Kualitatif: Teori dan Praktik. Jakarta: Bumi Aksara 
Idris, Meity H, dkk. (2015). Menumbuhkan Minat Membaca pada Anak Usia Dini.Jakarta: PT Luxima Metro Media.

Kalida, Muhsin. (2012). Strategi Networking PKBM. Yogyakarta: Cakruk Publishing. . (2014). PKBM di PKBM: Model dan Strategi Pengembangannya.Yogyakarta: Cakruk Publishing.

Kementerian Pendidikan dan Kebudayaan. (2016). Petunjuk Teknis Program Kampung Literasi dan Pengajuan Bantuan Tahun 2016. Jakarta: Direktorat Pembinaan Pendidikan Keaksaraan dan Kesetaraan Dirjen PAUDNI.

Kementrian Pendidikan dan Kebudayaan. (2017). Panduan Penyelenggaraan Program Kampung Literasi. Jakarta: Direktorat Jenderal Pendidikan Anak Usia Dini dan Pendidikan Masyarakat Direktorat Pembinaan Pendidikan Keaksaraan dan Kesetaraan.

Ratnasari, Puspita. (2011). Asyiknya Membaca. Jakarta: Prestasi Pustaka Anak.

Salim \& Formen. (2006). Teori \& Paradigma Penelitian Sosial. Yogyakarta: Tiarawacana

Sudarsana, Undang. (2015). Pembinaan Minat Baca. Tangerang Selatan: Universitas Terbuka

Sugiyono. (2016). Metode Penelitian Pendidikan Pendekatan Kuantitatif,Kualitatif, dan R \& D. Bandung: Alfabeta

Sutarno. (2011). Perpustakaan dan Masyarakat. Jakarta: Buku Obor.

UNESCO. (2011). Creating And Sustaining Literate Environments. Bangkok, Thailand: UNESCO Bangkok.

Journal

SEWAGATI, Jurnal Pengabdian kepada Masyarakat - LPPM ITS Vol. 2 No. 12018 e-ISSN 2613-9960 ( https://www.researchgate.net/publication/325652860 )

Khoiruddin, M.Arif. (2016). Menumbuhkan Minat Baca Sejak Dini di Taman Baca Masyarakat Journal An-nafs, Vol. 1 No.2 Desember 2016.

Shofaussamawati. (2014) Menumbuhkan Minat Baca dengan PengenalanPerpustakaan Pada Anak Sejak Dini. Libraria, Vol.2 No.1

Yanto, A., Rodiah, S. \& Lusiana, E. (2016). Model Aktivitas Gerakan Literasi Berbasis Komunitas Di Sudut Baca Soreang. Jurnal Kajian Informasi dan Perpustakaan. Vol. 2 No. 1, Juni 2016.

Siswati,(2010) Minat Membaca Pada Mahasiswa (Studi Deskriptif pada Mahasiswa Fakultas Psikologi UNDIP Semester I) Jurnal Psikologi Undip Vol. 8, No.2, Oktober 2010 